\title{
Jumlah Total Bakteri dan Bakteri Coliform Pada Air Laut dan Sedimen Perairan Laut Kecamatan Kendal
}

\author{
Husna Hanifah*, Jusup Suprijanto, Subagiyo \\ Departemen IImu Kelautan, Fakultas Perikanan dan Ilmu Kelautan, Universitas Diponegoro \\ Jl. Prof. H. Soedarto S.H, Tembalang, Semarang, Jawa Tengah 50275 Indonesia \\ *Corresponding author, e-mail : husnahanifah@students.undip.ac.id
}

\begin{abstract}
ABSTRAK: Perairan Laut Kendal terhubung dengan Sungai Buntu, Sungai Kendal, dan Sungai Blorong yang membawa limbah dari kegiatan di darat seperti Mandi Cuci Kakus (MCK), peternakan, tambak, pertanian, dan kegiatan kapal dan Tempat Pelelangan Ikan (TPI). Hal ini akan mempengaruhi kualitas bakteriologis perairan laut Kecamatan Kendal. Penelitian ini dilakukan untuk menganalisa kualitas bakteriologis air dan sedimen perairan laut Kecamatan Kendal berbasis jumlah total bakteri dan Coliform. Sampel air laut dan sedimen diambil pada bulan Oktober Tahun 2019. Analisa bakteriologis dilakukan di Laboratorium Balai Pengujian Mutu Hasil Perikanan Semarang menggunakan metode berdasarkan ISO 6222: 1999 dan SNI 01-2332.3 2015, SNI ISO 9308 -1: 2010 dan SNI 01-2332.1 - 2006. Hasil penelitian menunjukkan jumlah total bakteri pada sampel air laut di stasiun 1 berkisar antara $190 \mathrm{Cfu}$ - $240 \mathrm{Cfu}$, di stasiun 2 antara $340 \mathrm{Cfu}$ - $380 \mathrm{Cfu}$. Jumlah total Coliform pada sampel air laut di stasiun 1 dan 2 adalah $1 \mathrm{Cfu} / 100$ $\mathrm{ml}$. Jumlah total bakteri pada sampel sedimen di stasiun 1 dan 2 yaitu antara $19.000 \mathrm{Cfu}-90.000$ Cfu dan jumlah total coliform di kedua stasiun tersebut sebesar 3,6 MPN/g Coliform. Nilai total Coliform ini berada dibawah baku mutu air laut untuk biota laut, yang maksimum adalah 1.000 dengan toleransi $<10 \%$. Sedangkan untuk jumlah total bakteri tidak diatur dalam baku mutu air laut. Tetapi secara umum jumlah total bakteri di air laut terdapat $10^{6} \mathrm{sel} / \mathrm{ml}$. Sehingga nilai hasil analisis total bakteri menunjukkan kualitas air laut yang masih baik.
\end{abstract}

Kata kunci: Angka Lempeng Total; Coliform; Sedimen; Air Laut

\section{The Total Number of Bacteria and Coliform Bacteria in Sea Water and Sediment from Kendal Waters}

ABSTRACT: Kendal sea waters are connected to the Buntu River, Kendal River, and the Blorong River which carry waste from human activities such as domestic waste, fishery, agriculture, ship activities, and fish auction activities. These activities can influence the bacteriological quality of the waters of Kendal District. This research was conducted to analyze the bacteriological quality of seawater and sediments from Kendal Seawaters based on the total number of bacteria and Coliform. Seawater and sediment samples were taken on October 2019. Bacteriological analysis was conducted at the Semarang Fisheries Product Quality Testing Laboratory (BPMHP) using methods based on ISO 6222: 1999 and SNI 01-2332.3 - 2015, SNI ISO 9308-1: 2010 and SNI 012332.1 - 2006. The results showed the total number of bacteria in sea water samples at station 1 ranged from $190 \mathrm{Cfu}$ - $240 \mathrm{Cfu}$, at station 2 between $340 \mathrm{Cfu} 380 \mathrm{Cfu}$. The total amount of Coliform in seawater samples at station 1 and 2 are $1 \mathrm{Cfu} / 100 \mathrm{ml}$. The total number of bacteria in sediment samples at station 1 and 2 are between 19,000 Cfu-90,000 Cfu and the total number of coliforms at both stations are 3.6 MPN / $g$ Coliform. The total value of this coliform is below the sea water quality standard for marine life, the maximum is 1,000 with a tolerance of $<10 \%$. Where as the total number of bacteria is not regulated in the seawater quality standard. But in general the total number of bacteria in seawater is 106 cells $/ \mathrm{ml}$. So the value of the total bacterial analysis shows that the quality of sea water is still good.

Keywords: Total Plate Count; Coliform; Sediment; Sea Water 


\section{PENDAHULUAN}

Kualitas hasil perikanan tangkap baik demersal maupun pelagic diantaranya dipengaruhi oleh kualitas bakteriologis perairan terutama patogen. Beberapa jenis produk perikanan diketahui mampu mengakumulasi patogen seperti kerang (Mok et al., 2016). Sichewo et al. (2014) dalam sitasinya menyatakan bahwa produk perikanan dapat terkontaminasi oleh bakteri patogen yang ada di lingkungan hidupnya. Hal ini telah direview oleh Novoslavskij (2015) bahwa jenis bakteri yang ada di kulit ikan adalah sama dengan yang ada di lingkungan. Lebih lanjut juga dijelaskan bahwa prevalensi patogen pada hasil perikanan diantaranya dipengaruhi oleh kontaminasi pada perairan. Kejadian ini dibuktikan oleh penelitian Jeamsripong et al. (2018) yaitu ditemukannya Salmonella dan Escherichia coli pada tiram. Kontaminasi laut oleh patogen terjadi diantaranya melalui aktivitas di darat dan aktivitas di pantai itu sendiri. Patogen masuk ke perairan laut terutama melalui jalur aliran air sungai.

Perairan laut Kendal merupakan zona penangkapan ikan. Sehingga kualitas dan keamanan produk hasil tangkapan dipengaruhi oleh kualitas bakteriologis perairan laut. Perairan Laut Kendal terhubung dengan beberapa sungai. Sungai Buntu dan Sungai Kendal berada di Kecamatan Kendal, sedangkan Sungai Blorong berada di wilayah Kecamatan Brangsong (BPS Kabupaten Kendal, 2019). Kualitas sungai pada Kawasan padat penduduk dapat dipengaruhi oleh kegiatan di sekitarnya seperti tambak dan pembuangan sampah pada sungai (Setiawan et al., 2019). Sehingga potensial terjadinya pencemaran sungai oleh limbah domestik (Sutiknowati, 2018), limbah pasar, limbah kapal, serta limbah TPI (Widyaningsih et al., 2016), limbah dari industri pengolahan limbah, sampah dan limbah peternakan (Sutiknowati, 2018), serta aktifitas perdagangan, pariwisata, dan pelayaran (Askar et al., 2018). Pencemaran ini diantaranya adalah kontaminasi bakteri patogen, virus, dan parasit lainnya (Widyaningsih et al., 2016). Salah satu indikator kualitas bakteriologis perairan adalah bakteri Coliform. Penelitian mengenai Coliform pada berbagai perairan telah dilakukan diantaranya adalah di Kendal (Agustiningsih et al., 2012), Jepara (Widyaningsih et al., 2016), dan Demak (Safitri et al., 2018). Kontaminasi bakteri ini diantaranya disebabkan oleh aktivitas permukiman, pertanian dan industri (Samudro, Agustiningsih \& Sasongko, 2012), kegiatan pelabuhan, tempat bersandar kapal nelayan, serta kegiatan perikanan yang ada di sekitar perairan (Widyaningsih et al., 2016), dan pemukiman penduduk, industri wisata dan aktifitas nelayan (Safitri et al., 2018). Oleh karena itu penelitian ini dilakukan untuk mengetahui bagaimana kualitas bakteriologis perairan pantai Kecamatan Kendal terkait dengan keamanan produk tangkapan.

\section{MATERI DAN METODE}

Materi penelitian adalah air laut dan sedimen dari perairan laut Kecamatan Kendal. Sampling dilakukan pada bulan Oktober tahun 2019. Sampel air laut diambil secara langsung dengan kedalaman sekitar $1 \mathrm{~m}$ dari permukaan. Sampel sedimen diambil menggunakan sedimen grab. Pengukuran suhu air, pH, salinitas dan oksigen terlarut (Askar et al., 2018), dilakukan bersama dengan pengambilan sampel air laut. Sampel air dan sedimen selanjutnya dilakukan pengujian bakteriologis di Balai Pengujian Mutu dan Hasil Perikanan. Pengujian bakteriologis air laut dilakukan menggunakan ISO 6222: 1999 dan SNI ISO 9308-1: 2010, sedangan pengujian sampel sedimen dilakukan menggunakan SNI 01-2332.2-2015 dan SNI 01-2332.1-2006. Semua data hasil penelitian di analisis dengan metode deskriptif (Partino dan Idrus, 2009 dalam Notowinarto dan Agustina, 2015).

\section{HASIL DAN PEMBAHASAN}

Hasil analisa bakteriologis pada sampel air laut dan sedimen bulan Oktober 2019 dari perairan laut Kecamatan Kendal menunjukkan jumlah total bakteri pada sampel air laut stasiun 1

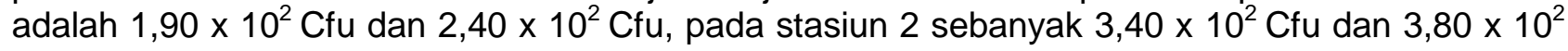
Cfu. Jumlah total Coliform di kedua staisun sebanyak $1 \mathrm{Cfu} / 100 \mathrm{ml}$. Sedangkan hasil Analisa jumlah total bakteri pada sampel sedimen stasiun 1 dan 2 masing-masing sebanyak $1,90 \times 10^{4} \mathrm{Cfu}$ 
dan $9,0 \times 10^{4} \mathrm{Cfu}$. Jumlah total Coliform di kedua stasiun sebanyak 3,6 APM/g. Secara lengkap hasil analisis ini ditampilkan pada Tabel 1.

Kementerian Negara lingkungan hidup melalui keputusannya bernomor 51 tahun 2004 telah menetapkan baku mutu air laut diantaranya adalah untuk biota laut. Pada peraturan ini ditetapkan bahwa baku mutu air laut untuk biota laut pada parameter mikrobiologis adalah jumlah total Coliform maksimum 1000 MPN/ $100 \mathrm{ml}$ dengan toleransi < 10\% dan keberadaan patogen adalah nihil. Baku mutu ini relevan untuk diterapkan pada perairan laut yang ditetapkan sebagai zona penangkapan ikan. Hasil penelitian di perairan Kecamatan Kendal menunjukkan nilai bakteri Coliform pada air laut sebesar 1-100 Cfu/ $100 \mathrm{~mL}$. Nilai ini jauh di bawah baku. Bakteri Coliform memiliki daya tahan yang baik di dalam perairan laut (Sutiknowati, 2018), meskipun demikian keberadaan bakteri dipengaruhi oleh banyak faktor yaitu salinitas (Karbasdehi et al., 2017), suhu (Blaustein et al., 2013), pH dan DO (Wahyuni, 2017), cahaya dan tekanan hidrostatik (Sutiknowati, 2018). Keberadaannya bakteri Coliform di laut tidak dapat berlangsung lama pada salinitas yang tinggi (> 30\%o) (Ruyitno, 2008 dalam Sutiknowati, 2018).

Kai et al. (2017) dalam sitasinya menyatakan bahwa jumlah bakteri di kolom air laut berada pada nilai $>10^{5} \mathrm{sel} / \mathrm{ml}$. Pada penelitian ini diperoleh jumlah total bakteri di kolom air perairan laut kecamatan Kendal sebanyak $1.90 \times 10^{2}-3,80 \times 10^{2} \mathrm{Cfu} / \mathrm{ml}$. Jika mengacu dari pernyataan Kai et al. (2017) menunjukkan bahwa kelimpahan bakteri di kolom air perairan laut kecamatan Kendal masuk kategori kepadatan yang rendah.

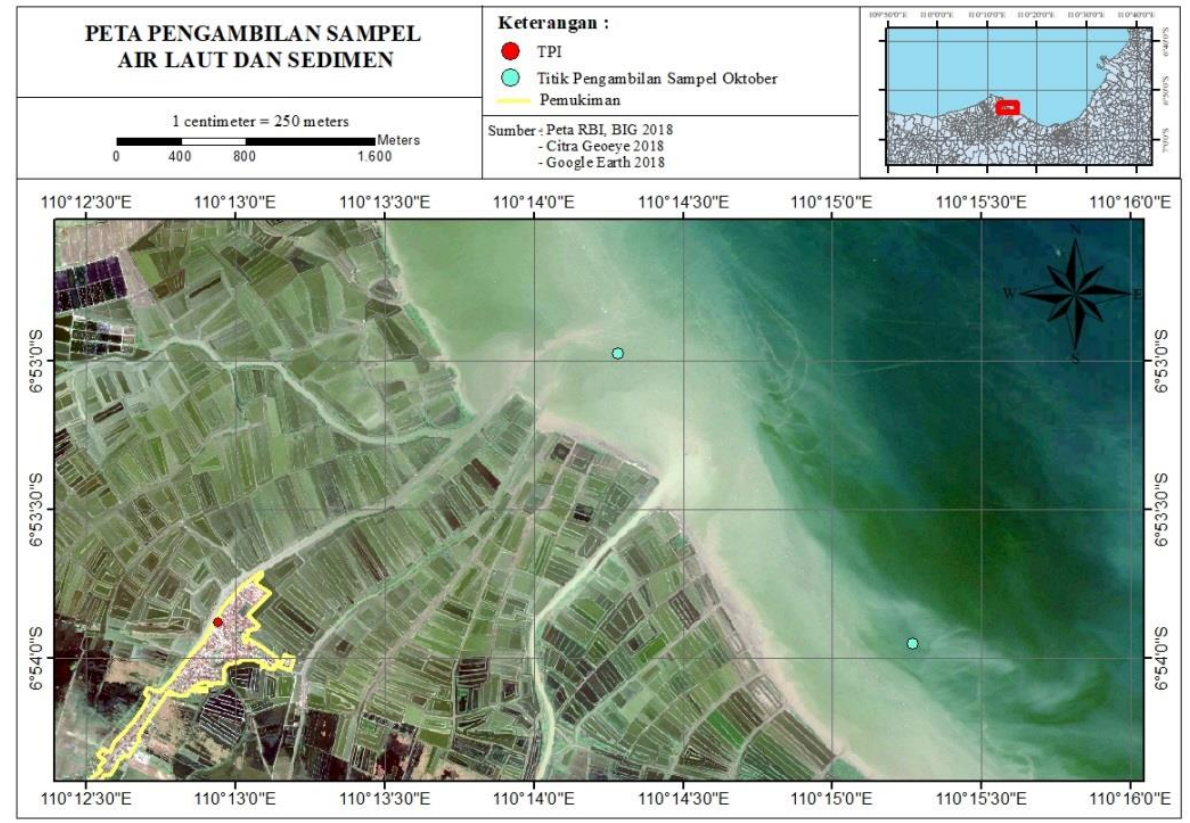

Gambar 1. Peta Lokasi dan Stasiun Penelitian di Perairan Laut Kecamatan Kendal

Tabel 1. Analisis Bakteriologis Air dan Sedimen Perairan Laut Kecamatan Kendal

\begin{tabular}{|c|c|c|c|c|}
\hline \multirow{2}{*}{ Parameter } & \multicolumn{2}{|c|}{ Air } & \multicolumn{2}{|c|}{ Sedimen } \\
\hline & St.1 & St.2 & St.1 & St.2 \\
\hline Jumlah total bakteri (ALT) & & & & \\
\hline $\mathrm{Cfu} / \mathrm{ml}^{1)}$ & $1,90 \times 10^{2} \mathrm{Cfu} / \mathrm{ml}^{\mathrm{a}}$ & $3,40 \times 10^{2} \mathrm{Cfu} / \mathrm{ml}^{\mathrm{a}}$ & & \\
\hline $\begin{array}{c}\mathrm{Cfu} / \mathrm{g}^{2)} \\
\text { Jumlah total Coliform }\end{array}$ & $2,40 \times 10^{2} \mathrm{Cfu} / \mathrm{ml}^{\mathrm{b}}$ & $3,80 \times 10^{2} \mathrm{Cfu} / \mathrm{ml}^{\mathrm{b}}$ & $1,90 \times 10^{4} \mathrm{Cfu} / \mathrm{g}$ & $9,0 \times 10^{4} \mathrm{Cfu} / \mathrm{g}$ \\
\hline $\begin{array}{c}\mathrm{Cfu} / 100 \mathrm{ml}^{3)} \\
\mathrm{APM} / \mathrm{g})^{4)}\end{array}$ & $1 \mathrm{Cfu} / 100 \mathrm{ml}$ & $1 \mathrm{Cfu} / 100 \mathrm{ml}$ & 3,6 APM $/ g$ & 3,6 APM/g \\
\hline
\end{tabular}

Keterangan :1) ISO 6222: 1999; 2) SNI 01-2332.3 - 2015; 3) SNI ISO 9308 -1: 2010; 4) SNI 012332.1 - 2006; a adalah suhu inkubasi $22^{\circ} \mathrm{C}$; b adalah suhu inkubasi $37^{\circ} \mathrm{C}$ 
Beberapa penelitian lain dilaporkan oleh Kunarso \& Agustin, 2012 dalam penelitiannya di perairan Selat Flores pada lapisan permukaan didapatkan rata-rata jumlah bakteri heterotrof sebanyak $3,70 \times 10^{2} \mathrm{Cfu} / \mathrm{ml}$ dan di perairan Selat Bolling rata-rata 2,6 $\times 10^{2} \mathrm{Cfu} / \mathrm{ml}$. Kunarso \& Agustin, 2012 dalam sitasinya melaporkan jumlah bakteri di perairan pulau Enggano $59,7 \times 10^{2}$ $\mathrm{Cfu} / \mathrm{ml}$, di perairan Muara Digul dan laut Arafura $46 \times 10^{2} \mathrm{Cfu} / \mathrm{ml}$ dan di perairan Selat Makassar $2,90 \times 10^{2} \mathrm{CFU} / \mathrm{ml}$. Ada banyak faktor yang mempengaruhi kelimpahan bakteri pada air laut.

Silva et al. (2019) dalam sitasinya menyebutkan bahwa di antara semua faktor yang mungkin mempengaruhi kelimpahan dan produktivitas bakteri heterotrofik adalah ketersediaan sumber daya (nutrisi anorganik dan organik dan sumber karbon), kematian karena grazing oleh protista dan lisis karena virus dan suhu air, cahaya atau salinitas. Pada penelitian ini tidak dilakukan kegiatan pengukuran faktor-faktor pembatas ini. Sehingga tidak dapat dikaji bagaimana kondisi faktor pembatas kelimpahan dan pertumbuhan bakteri di lokasi penelitian.

Bakteri yang masuk ke perairan laut dapat tetap berada di kolom air atau terendap dan terikat di sedimen. Gelombang dan arus yang tenang dapat menyebabkan bakteri terendap bersama dengan partikel-partikel sedimen. Beberapa faktor yang berpengaruh pada terikatnya bakteri di sedimen antara lain : sedimen sebagai tempat untuk melekatnya mikroba itu sendiri, terdapat zat organik dan nutrisi yang menguntungkan bagi mikroba, serta sedimen dapat melindungi bakeri dari tekanan lingkungan seperti sinar matahari UV, dan adanya zat polimer ekstraseluler bakteri. Secara umum, bakteri indikator dapat tetap hidup lebih lama di sedimen daripada di kolom air baik tawar maupun laut (Karbasdehi et al., 2017).

Hasil analisa jumlah total bakteri pada sampel sedimen bulan Oktober 2019 stasiun 1 dan 2 yaitu $1,9 \times 10^{4} \mathrm{Cfu}$ dan $9,0 \times 10^{4} \mathrm{Cfu}$. Hasil uji jumlah total bakteri pada sedimen lebih tinggi dibandingkan dengan air, menurut Karbasdehi et al. (2017), hal tersebut dikarenakan bakteri dapat mengendap di sedimen dengan gelombang dan arus yang tenang. Notowinarto dan Agustina (2015) menyebutkan bahwa habitat bakteri cenderung menempel pada sedimen atau bahan padatan lain.

Penelitian mengenai keberadaan bakteri pada sedimen pernah dilakukan sebelumnya oleh beberapa peneliti, adapun jenis bakteri yang diteliti berbeda-beda, antara lain: Coliform (Askar et al., 2018), Salmonella dan Vibrio (Sutiknowati et al., 2012). Kondisi lingkungan sedimen yang mendukung dapat mengikat bakteri untuk tumbuh dan berkembang di dalamnya (Karbasdehi et al., 2017). Bakteri Coliform yang telah masuk ke perairan dapat mengendap dan berkembang di dalam sedimen. Jumlah bakteri Coliform pada sedimen dipengaruhi oleh aktivitas yang menyebabkan terjadinya pengadukan pada perairan, sedimen yang tidak teraduk memiliki jumlah bakteri yang lebih tinggi jika dibandingkan dengan sedimen yang teraduk karena mengalami resuspensi akibat dari suatu aktivitas (Askar et al., 2018).

Pengujian Coliform pada sampel sedimen dilakukan sama dengan metode pengujian sampel produk perikanan secara umum, yaitu menggunakan tabung 3 seri. Hasil analisa sampel sedimen bulan Oktober 2019 pada stasiun 1 dan 2 menunjukkan hasil adanya bakteri Coliform sebanyak 3,6 APM/ g, sehingga dimungkinkan pada bulan Oktober 2019 kondisi perairan laut Kecamatan Kendal mendapat banyak pengaruh dari darat maupun kegiatan yang mendorong terjadinya pencemaran bahan organik.

\section{KESIMPULAN}

Perairan laut Kecamatan Kendal pada bulan Oktober 2019 memiliki kualitas bakteriologis yang baik berdasarkan jumlah total bakteri dan Colifom. Sehingga mendukung kehidupan biota laut dengan tingkat keamanan yang baik. Rendahnya kelimpahan Coliform mengindikasikan bahwa lingkungan perairan tidak tercemar secara bakteriologis. Jika kondisi ini relatif sama sepanjang tahun maka produk perikanan tangkap dari area ini aman untuk dikonsumsi (kemungkinan terkontaminasi patogen sangat rendah). Untuk mendapatkan justifikasi yang baik perlu dilakukan penelitian runtut waktu dalam 1 tahun atau lebih untuk menggambarkan dinamika kondisi yang sebenarnya. 


\section{UCAPAN TERIMAKASIH}

Artikel ini adalah bagian dari skripsi dengan judul "Analisis Kualitas Bakteriologis Air Laut, Sedimen, dan Udang dari Perairan Laut Kendal Berdasarkan Jumlah Total Bakteri, Bakteri Coliform, Escherichia coli, dan Salmonella" untuk memperoleh gelar Sarjana Strata Satu pada Departemen IImu Kelautan, Fakultas Perikanan dan IImu Kelautan, Universitas Diponegoro, Semarang.

\section{DAFTAR PUSTAKA}

Askar, A.T., Agung, M.U.K., Andriani, Y. \&Yuliadi, L.P. 2018. Kelimpahan Bakteri Coliform Pada Air Laut, Sedimen dan Foraminifera Jenis Calcarina di Ekosistem Terumbu Karang Pulau Pramuka, Kepulauan Seribu, DKI Jakarta. Jurnal Akuatika Indonesia, 3(1):36 - 41.

Badan Pusat Statistik Kabupaten Kendal. 2019. Kecamatan Brangsong dalam Angka 2019. Badan Pusat Statistik Kabupaten Kendal, Kendal, 100 hlm.

Badan Pusat Statistik Kabupaten Kendal. 2019. Kecamatan Kendal dalam Angka 2019. Badan Pusat Statistik Kabupaten Kendal, Kendal, $101 \mathrm{hlm}$.

Blaustein, R.A., Pachepsky, Y., Hill, R.L., Shelton, D.R. \& Whelan, G., 2013. Escherichia coli survival in waters: temperature dependence. Water research, 47(2):569-578.

Jeamsripong, S., Chuanchuen, R., \& Atwill, E.R. 2018. Assessment of Bacterial Accumulation and Environmental Factors in Sentinel Oysters and Estuarine Water Quality from the Phang Nga Estuary Area in Thailand. International Journal of Environmental Research and Public Health, $15: 1-17$. DOI : 10.3390/ijerph15091970

Kai, W., Peisheng, Y., Rui, M., Wenwen, J. \& Zongze, S., 2017. Diversity of culturable bacteria in deep-sea water from the South Atlantic Ocean. Bioengineered, 8(5):572-584. DOI : 10.1080/21655979.2017.1284711

Karbasdehi, V.N., Dobaradaran, S., Nabipour, I., Ostovar, A., Arfaeinia, H., Vazirizadeh, A., Mirahmadi, R., Keshtkar, M., Ghasemi, F.F. \& Khalifei, F., 2017. Indicator bacteria community in seawater and coastal sediment: the Persian Gulf as a case. Journal of Environmental Health Science and Engineering, 15(1):1-15. DOI 10.1186/s40201-017-0266-2

Kunarso, D.H. \& Agustin, T.I. 2012. Kajian Bakteri Heterotropik di Perairan Laut Lamalera. IImu Kelautan, 17(2):63-73.

Mok, J.S., Lee, T.S., Kim, P.H., Lee, H.J., Ha, K.S., Shim, K.B., Lee, K.J., Jung, Y.J. \& Kim, J.H., 2016. Bacteriological quality evaluation of seawater and oysters from the Hansan-Geojeman area in Korea, 2011-2013: impact of inland pollution sources. Springerplus, 5(1):1412. DOI : 10.1186/s40064-016-3049-9

Notowinarto \& F. Agustina. 2015. Populasi Bakteri Heterotrof di Perairan Pulau Bulang Batam. Jurnal Pendidikan Biologi Indonesia,1 (3) : 334 - 342.

Novoslavskij, A., Terentjeva, M., Eizenberga, I., Valciņa, O., Bartkevičs, V. \& Bērzinš̌, A., 2016. Major foodborne pathogens in fish and fish products: a review. Annals of microbiology, 66(1):1-15. DOI : 10.1007/s13213-015-1102-5

Safitri, L.F., Widyorini, N. \& Jati, O.E. 2018. Analisis Kelimpahan Total Bakteri Coliform di Perairan Muara Sungai Sayung, Morosari, Demak. Saintek Perikanan : Indonesian Journal of Fisheries Science and Technology, 14(1):30 - 35.

Samudro, S., Agustiningsih, D., \& Sasongko, S.B. 2012. Analisis Kualitas Air dan Strategi Pengendalian Pencemaran Air Sungai Blukar Kabupaten Kendal. Jurnal Presipitasi: Media Komunikasi dan Pengembangan Teknik Lingkungan, 9 (2):64-71.

Saraswati, N.L.G.R.A., Rustam, A., Salim, H.L., Heriati, A. \& Mustikasari, E., 2017. Kajian Kualitas Air Untuk Wisata Bahari Di Pesisir Kecamatan Moyo Hilir Dan Kecamatan Lape, Kabupaten Sumbawa. Jurnal Segara, 13(1):37 - 47.

Setiawan, K., Purnomo P.W., \& Suprapto, D. 2019. Kajian Kualitas Air Kawasan Pertambakan di Sungai Buntu, Kendal. Journal of Maquares, 8 (3):162 - 168.

Sichewo, P.R., Gono, R.K., Muzondiwa, J. \& Mungwadzi, W., 2014. Isolation and identification of pathogenic bacteria in edible fish: A case study of rural aquaculture projects feeding livestock 
manure to fish in Zimbabwe. International Journal of Current Microbiology and Applied Sciences, 3(11):897-904.

Silva, L., Calleja, M.L., Huete-Stauffer, T.M., Ivetic, S., Ansari, M.I., Viegas, M. \& Morán, X.A.G2019. Low Abindances but High Growth Rates of Coastal Heterotrophic Bacteria in the Red Sea. Frontiers in Micribiology, 9 : 3244. DOI : 10.3389/fmicb.2018.03244

Sutiknowati, L.I. 2018. Keragaman Bakteri pada Perairan Sabang, Provinsi Aceh. Majalah IImiah Biologi Biosfera : A Scientific Journal, 35 (2) : $54-62$.

Wahyuni, E. A. 2017. Karakteristik pH dan Pengaruhnya Terhadap Bakteri Coliform di Perairan Selat Madura Kabupaten Pamekasan. Jurnal IImu-IImu Perairan, Pesisir dan Perikanan, 6(3):214-220. DOI: 10.13170/depik.6.3.5875

Widyaningsih, W., Supriharyono, \& Widyorini, N. 2016. Analisis Total Bakteri Coliform di Perairan Muara Kali Wiso Jepara. Diponegoro Journal of Maquares, 5(3):157-164. 